\title{
Nitrogen allocation and recycling in peri-urban mixed crop-livestock farms in Ethiopia
}

\author{
Solomon Tulu Tadesse $\mathbb{D} \cdot$ Oene Oenema $\cdot$ Christy van Beek $\cdot$ Fikre Lemessa Ocho
}

Received: 22 February 2018/ Accepted: 10 October 2018/Published online: 20 October 2018

(C) The Author(s) 2018

\begin{abstract}
Mixed crop-livestock (MC-LS) farms are assumed to be more environmental friendly than specialized livestock systems, due to their better options for internal nutrient recycling. However, there are large differences among MC-LS farms in nutrient allocation and recycling. Here, we posit that the relative allocation of nitrogen to crop and livestock compartments, expressed as crop-livestock ratio (CLS), determines the performance of MC-LS farms. Among 300 urban and peri-urban farms studied in 2014, 42 MC-LS farms (Addis Ababa: 20; Jimma: 22) were re-interviewed in 2016, using MonQIt (monitoring tool) questionnaire. The performances of these farms were evaluated using partial nitrogen balance
\end{abstract}

S. T. Tadesse ( $\square)$

Department of Soil Quality, Wageningen University and Research, P. O. Box 47, 6700 AA Wageningen,

The Netherlands

e-mail: soltuta@gmail.com;

solomon.tadesse@wur.nl

S. T. Tadesse $\cdot$ F. L. Ocho

Department of Horticulture and Plant Sciences, College of Agriculture and Veterinary Medicine, Jimma University,

P. O. Box 307, Jimma, Ethiopia

O. Oenema

Wageningen Environmental Research, P. O. Box 47, 6700 AA Wageningen, The Netherlands

C. van Beek

Soil Cares Foundation, Nieuwe Kanaal 7c,

6709 PA Wageningen, The Netherlands
(PNB), $\mathrm{N}$ use efficiency (NUE), $\mathrm{N}$ recycling index and net farm income (NFI). CLS was negatively related to $\mathrm{N}$ input, PNB and NFI. Livestock oriented MC-LS farms had 4-5 times higher $\mathrm{N}$ input and 7 times higher PNB than crop oriented MC-LS farms, because they had 2-4 times higher NFI and purchased more external $\mathrm{N}$ input. This indicated that $\mathrm{N}$ allocation has significant environmental and economic implications. Sensitivity analyses suggested that NUE at farm system level can be improved by $20-25 \%$ and $\mathrm{N}$ recycling (NR) by $10-20 \%$ over the current condition. In conclusion, MC-LS farms are diverse, and much of the diversity can be captured by the CLS indicator. NUE and NR of peri-urban MC-LS farms in Ethiopia can be significantly improved through NUE enhancing measures: targeted exchange of crop residues and manure between crop and livestock activities within and between farms and improving animal NUE through breeding and precision feeding.

Keywords Crop-livestock ratio (CLS) .

Smallholder · NUE · Food security · Circular economy

\section{Introduction}

Urban and peri urban agriculture (UPA) provides significant contributions to the food security of most low income countries (Satterthwaite et al. 2010). 
Millions of urban residents currently depend on UPA for both food consumption and income. For instance, in urban and peri-urban areas of East Africa, 17-36\% of the population grow crops (C) and/or keep livestock (LS) (Satterthwaite et al. 2010). Large share of UPA farms are mixed crop-livestock (MC-LS) systems, i.e., produce both crops and animals in variable proportions. These MC-LS systems produce half of the current world's food (Duncan et al. 2013). For instance, these systems produce $50 \%$ of world cereals, $34 \%$ of global beef and $30 \%$ of global milk. MC-LS systems also produce $65 \%$ beef, $75 \%$ milk and $55 \%$ lamb in the developing world (Tarawali et al. 2011) and support the livelihood of more than $80 \%$ of the population living in the developing part of the world (Blummel et al. 2013). These MC-LS systems are also the backbone of African agriculture, ensuring hundreds of millions of people are food secure (Tarawali et al. 2011).

Globalization, urbanization and income growth are fuelling substantial increases in the demand for animal derived food, especially in rapidly developing countries (Thornton 2010). In response to the increasing food demand of the urban population, MC-LS periurban farms are recognized as multifunctional systems that provide a significant fraction of the necessary food, through both crop and livestock production activities (Zasada 2011). Due to the multi-functionality of these systems, the crop (C) and livestock (LS) compartments within MC-LS farms can be either complementary or competitive. Complementarity occurs when one farm compartment provides inputs to the other. A trade off (or competition) occurs when a resource is allocated to one compartment at the expense of another; for example, the available cash money may be used to buy fertilizer instead of animal feed, and crop residues may be used for animal feed instead of soil fertility amendment (Valbuena et al. 2015). The trade-off will be small in the second case if the resulting animal manures are returned to the cropland. Complementarity between farm compartments is efficiently employed when the cropland provides the feed for the animals and all manures are returned to the cropland. In such mixed systems nutrients are efficiently recycled between crop and livestock compartments, which may strengthen environmental sustainability (Gupta et al. 2012). When household wastes are also returned to livestock and/or crop land, smallholder mixed farming systems can be considered a circular economy (Cassidy et al. 2013). Consequently, MC-LS systems are assumed to be more environmental friendly and sustainable than specialized crop production and animal production systems (Marton et al. 2016; Sneessens et al. 2016). In UPA, specialized crop production systems often rely on the import of fertilizer nutrients, while specialized animal production rely on the import of animal feed and have great difficulties with appropriate manure disposal, for example, Strokal et al. (2016) and Liu et al. (2017). However, MC-LS systems are under pressure of the market regime, as specialized crop production and animal production systems often produce at lower costs than mixed systems. This could be due to the higher resource constraints leading to competition between crop and livestock compartments in MC-LS systems and relatively the small size of MC-LS systems and the related economy of scale. Large specialized and intensive systems can often comply also much easier with the requirements of the food processing industries and suppliers, and thereby get more easy access to new information and technologies. A practical challenge facing MC-LS farms is therefore to achieve a sustainable increase in crop and livestock production within emerging resource constraints, especially in peri-urban areas (Goulding et al. 2008; Cassidy et al. 2013), and thereby to remain economically competitive. Thus, in resource constrained peri-urban areas, intensification of production may lead to competition between soil/crop and livestock compartments in MC-LS farms for land, crop residues and investments (Valbuena et al. 2015). The choice of investment and $\mathrm{N}$ allocation either to crop or livestock compartments may have implications for the environmental and economic performances of MC-LS farms (Tittonell et al. 2007). Thus, $\mathrm{N}$ allocation to either the soil/crop or the livestock compartments may differ considerably, also because MC-LS farms are heterogeneous with respect to the use of inputs (Ryschawy et al. 2012). Thus, understanding $\mathrm{N}$ allocation effects on the economic and environmental performances of MC-LS systems is vital to suggest $\mathrm{N}$ management options for enhancing NUE and $\mathrm{N}$ recycling (NR) in peri-urban MC-LS farms. Yet, there is no practical method to characterize nutrient allocation to soil/crop and livestock compartments in MC-LS farm systems, and there are no systematic analyses. This may hamper a proper assessment of environmental and economic 
performances of the MC-LS farms. Here, we report on a method for examining the impacts of $\mathrm{N}$ allocation in mixed farming systems. A set of five indicators was used to evaluate the environmental and economic performances of peri-urban MC-LS farms in Ethiopia.

\section{Materials and methods}

\section{Concept: $\mathrm{N}$ allocation and indicators}

Mixed crop-livestock (MC-LS) farms are composed of three compartments, i.e., soil/crop, livestock and household. The soil/crop and livestock compartments directly or indirectly provide food and income to the farm household, and the relative importance has impact on the nutrient flows (Rufino et al. 2009). MC-LS farms may differ in the relative allocation of external nutrient inputs to the soil/crop and livestock compartments. Accordingly, nutrient allocation indicates the relative quantity of nutrient flows either to the crop or livestock compartment depending on the relative importance of the crop or livestock compartment within a farm. In crop oriented MC-LS farms more investment is on external $\mathrm{N}$ input to the crop compartment than the livestock to get higher crop yield and residue to feed their livestock. In livestock oriented MC-LS farms more investment is on external $\mathrm{N}$ input to the livestock compartment than the crop to get higher milk yield and manure to fertilize their crop

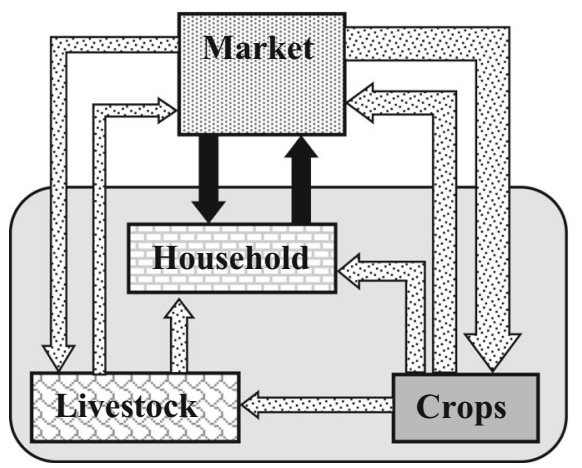

Fig. 1 Nutrient allocation in a MC-LS farm and direction of net flows between crop and livestock compartments of a farm and the market. The solid black arrows indicate the cash flows. The spotted white arrows indicate the direction of nutrient flows and their size indicates the quantity of nutrient flows depending on the relative importance of crop or livestock compartment within a farm. Accordingly, on the left: soil/crop oriented lands (Fig. 1). These differences in nutrient allocation in MC-LS farms may relate to economic opportunities, cultural preferences and availability of capital to purchase crop and livestock inputs (Kindu et al. 2014). MC-LS farms may allocate external nutrient inputs to the soil/crop or the livestock compartments, or both. The crop-livestock ratio (CLS) indicates the proportion of external nutrient inputs allocated to the crop compartment. Here, we express CLS in terms of N, because $\mathrm{N}$ is often the most limiting nutrient and a key factor in the intensification of agricultural production systems (Rufino et al. 2006).

To evaluate the impacts of $\mathrm{N}$ allocation in MC-LS farms, we used $\mathrm{N}$ input, $\mathrm{N}$ output, partial $\mathrm{N}$ balance (PNB), N use efficiency (NUE) and $\mathrm{N}$ recycling index (NRI) as $\mathrm{N}$ flow indicators and gross margins (GM) and net farm income (NFI) as farm profitability indicators. The indicators were calculated as follows.

CLS is the ratio between $\mathrm{N}$ input (IN) to the soil/ crop compartment and the sum of $\mathrm{N}$ inputs to both soil/ crop and livestock compartments (Eq. 1) as explained in van Beek et al. (2009).

$C L S=\frac{I N_{\text {crop }}}{I N_{\text {crop }}+I N_{\text {livestock }}}$

$\mathrm{N}$ input (IN) is the sum of inorganic ( $\left.\mathrm{I} 1_{\mathrm{N}}\right)$ and organic $\left(\mathrm{I}_{\mathrm{N}}\right) \mathrm{N}$ inputs (Eq. 2). Inorganic and organic $\mathrm{N}$ inputs are imported for crop and livestock activities of MC-LS farms and obtained from the MonQIt

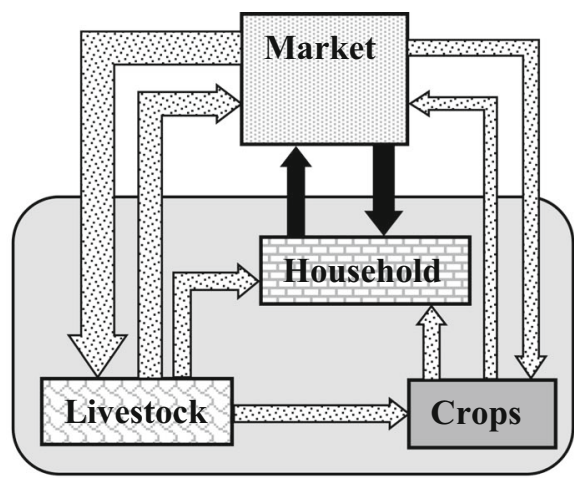

nutrient allocation (CLS > 0.5); the big arrow from market to crops indicates more nutrients flow to the soil/crop compartment than to the livestock. Right: livestock oriented nutrient allocation (CLS $<0.5$ ); the big arrow from market to livestock indicate more nutrients flow to the livestock compartment than to the soil/crop compartment 
(Monitoring for Quality Improvement tool) questionnaire ("Data collection" Section).

$I N=I 1_{N}+I 2_{N}$

$\mathrm{N}$ output $(\mathrm{ON})$ is the sum of $\mathrm{N}$ outputs in harvested crop, livestock and milk $\left(\mathrm{O} 1_{\mathrm{N}}\right)$ and crop residue and manure $\left(\mathrm{O} 2_{\mathrm{N}}\right)($ Eq. 3).

$O N=O 1_{N}+O 2_{N}$

Partial $\mathrm{N}$ balance (PNB) is the difference in farmer managed $\mathrm{N}$ inputs and $\mathrm{N}$ outputs (Eq. 4).

$P N B=I N-O N$

$\mathrm{N}$ use efficiency (NUE) is the ratio between the harvested $\mathrm{N}$ output and managed $\mathrm{N}$ inputs (Eq. 5) according to Wang et al. (2008).

$N U E=\frac{O N}{I N} * 100$

Total $\mathrm{N}$ (TN) use of the farm is the sum of $\mathrm{N}$ recycled (NR) in the farm and $\mathrm{N}$ input imported from external sources (IN) (Eq. 6) as indicated in Rufino et al. (2009).

$T N=N R+I N$

$\mathrm{N}$ recycling index (NRI) is the proportion of $\mathrm{TN}$ that is recycled (NR) (Eq. 7) as expressed by Rufino et al. (2009) and Banerjee et al. (2017).

$N R I=\frac{N R}{T N(N R+I N)}$
Goss Margin (GM) is calculated at the farm level (Eq. 8).

$G M=G V-V C$

where GV (gross value) is the value of the total output and VC (variable costs) is the costs of all inputs, over some accounting period (e.g. a year).

The net farm income (NFI) is derived from GM and the total fixed costs of the farm (Eq. 9).

$\mathrm{NFI}=\mathrm{GM}-\mathrm{FIXCOST}$

where FIXCOST is the total fixed costs of the farm (e.g. costs of dairy barn and etc.).

Study sites

Two contrasting cities in Ethiopia (Addis Ababa and Jimma) were selected as study area. The cities have a total population of 3.1 and 0.2 million and a population growth rate of 3.8 and 3\% per year, respectively (Haile Mariam and Adugna 2011). Addis Ababa is the political and economic capital of the country. Jimma is the commercial hub of the Southwestern part of the country and known as the origin of Coffee (Coffea arabica L.). The cities differ in their bio-physical characteristics and agro-ecology (Table 1). Addis Ababa has ten sub-cities and the majority of UPA farms are found in five sub-cities (Akaki-Kaliti, Bole,

Table 1 Agro-ecology and bio-physical features of Addis Ababa and Jimma urban and peri-urban areas

\begin{tabular}{|c|c|c|}
\hline Cities & Addis Ababa & Jimma \\
\hline Location & $9^{\circ} 1^{\prime} \mathrm{N}$ and $38^{\circ} 44^{\prime} \mathrm{E}$ & $7^{\circ} 40^{\prime} \mathrm{N}$ and $36^{\circ} 50^{\prime} \mathrm{E}$ \\
\hline Rainfall (mm/year) & 1165 & 1510 \\
\hline Altitude (m) & $2300-3000$ & 1780 \\
\hline $\begin{array}{l}\text { Mean low and high } \\
\text { temperature }\left({ }^{\circ} \mathrm{C}\right)\end{array}$ & 11 and 23 & 12 and 27 \\
\hline Major soil types & Chromic and Pellic Vertisol & Chromic Nitisol and Cambisol \\
\hline Agro-ecological zoning & Moderately warm to cool moist mid highlands & $\begin{array}{l}\text { Sub humid, moderately warm to cool mid } \\
\text { highlands }\end{array}$ \\
\hline Main crops & $\begin{array}{l}\text { Barley, beans, wheat, teff, potato, highland } \\
\text { oilseeds, highland pulses }\end{array}$ & $\begin{array}{l}\text { Coffee, tea, spices, wheat, teff, barley, maize, } \\
\text { sorghum, beans }\end{array}$ \\
\hline $\begin{array}{l}\text { Main livestock } \\
\text { categories }\end{array}$ & $\begin{array}{l}\text { Cattle mainly exotic dairy cows, local breed cows } \\
\text { and oxen, sheep and goat }\end{array}$ & $\begin{array}{l}\text { Cattle mainly exotic dairy cows, local breed cows } \\
\text { and oxen, sheep and goat }\end{array}$ \\
\hline Herd size (TLU/farm) & 9 & 6 \\
\hline Mean farm size (ha) & 1.5 & 1.4 \\
\hline
\end{tabular}


Kirkos, Kolfe-Keranio and Nifasilk-Lafto), and these were selected for this study. In Jimma all the eight districts within the city were selected. The UPA in Addis Ababa and Jimma are variable mixtures of dairy farms, vegetables farms, subsistence field crops farms and mixed crop-livestock (MC-LS) farms (Tadesse et al. 2018).

\section{Data collection}

Among 300 UPA farms interviewed in 2014, 42 farms (Addis Ababa: 20, Jimma: 22) were categorized as MC-LS farm types (Tadesse et al. 2018). These farms were selected and re-interviewed in 2016 using the standardized questionnaire of MonQIt (Monitoring for Quality Improvement tool) (van Beek et al. 2010). Farm management data on household composition, fields and farm characteristics and nutrient management data including use of inputs for the different crops and livestock activities, flows between activities, crop yields, animal production, sales, input and output prices were collected using the MonQIt model questionnaire. MonQIt is a tool for monitoring the management and performance of small-holder farming systems to understand and pave the ways for improvement in social, economic, agricultural and environmental conditions of farming systems (www. monqi.org; Vlaming et al. 2012). Data was entered into the MonQIt model, which combines the farm data with the background data on e.g. nutrient contents of products, conversion factors from farmer used units (e.g. head loads) to SI units, etc. Data on nutrient (e.g. $\mathrm{N}, \mathrm{P}$ and $\mathrm{K}$ ) contents of crops, crop residues, milk and manure were obtained from literature (Alvarez et al. 2014; Wang et al. 2016) and included in the background database of the model. Combination of farm surveys, field observations and modelling provided the basis for computing CLS, $\mathrm{N}$ flows and farm income indicators ("Concept: $\mathrm{N}$ allocation and indicators" Section).

\section{Data analysis}

An independent-samples $t$ test was conducted to test for significant differences in $\mathrm{N}$ flows and income between MC-LS farms with crop oriented $\mathrm{N}$ allocation and MC-LS farms with livestock oriented $\mathrm{N}$ allocation using an alpha level of 0.05. Linear regression of $\mathrm{N}$ allocation (CLS) versus $\mathrm{N}$ flows and
Table 2 Assumptions of $\mathrm{N}$ management options for the sensitivity analyses to explore the possible range of NUE at farm level of MC-LS farms in peri-urban areas of Addis Ababa and Jimma

\begin{tabular}{llll}
\hline $\begin{array}{l}\text { Options } \\
(\mathrm{OPT})\end{array}$ & $\begin{array}{l}\text { Manure N } \\
\text { loss } \\
\%\end{array}$ & $\begin{array}{l}\text { Manure N } \\
\text { recovery }\end{array}$ & $\begin{array}{l}\text { Fertilizer N } \\
\text { recovery }\end{array}$ \\
\hline 1 & 70 & 30 & 40 \\
2 & 30 & 60 & 40 \\
3 & 70 & 30 & 70 \\
4 & 70 & 60 & 70 \\
5 & 30 & 60 & 70 \\
\hline
\end{tabular}

NFI was done. Correlation analysis was done among N flows and farm income indicators. For all analysis, SPSS statistical software version 23 was used.

In addition, a range of sensitivity analyses were made to explore the possible range of values for NUE of MC-LS farms, as function of CLS, NRI and various additional measures for enhancing NUE and $\mathrm{N}$ recycling (NR) in MC-LS farms. NUE of livestock production systems depends on the NUE at animal level, the $\mathrm{N}$ losses from animal manure, the amounts and recoveries of applied manure $\mathrm{N}$ and fertilizers $\mathrm{N}$ in the harvested feed and the relative proportion of purchased feed versus farm grown feed (Liu et al. 2017). In MC-LS systems, NUE at system level depends on the NUE at animal level, amounts of sold crops and the amounts and recoveries of applied manure $\mathrm{N}$ and fertilizers $\mathrm{N}$ to the harvested crops. We extended the simple model of Liu et al. (2017) to analyse the effects of changes in the NUE at animal level, CLS, manure $\mathrm{N}$ recycling, emissions (e.g. $\mathrm{CH}_{4}$, $\mathrm{N}_{2} \mathrm{O}$ and $\mathrm{NH}_{3}$ ) and their mitigation measures (appropriate manure handling, storage and application to reduce manure $\mathrm{N}$ losses), and of manure and fertilizer $\mathrm{N}$ recovery enhancing measures on the NUE of MCLS farms. NUE values ranging from 5 to $35 \%$ at animal level were combined with five $\mathrm{N}$ management options (Table 2), and with different CLS values.

\section{Results}

General characteristics of the farms

The peri-urban MC-LS farms of the two cities differed in farm land size and number of plots, management, 
Table 3 Mean characteristics (standard deviations between brackets) of MC-LS farms in Addis Ababa and Jimma
${ }^{\mathrm{a}} 1000$ ETB (Ethiopian Birr) $=43$ USD (January 2018)

\begin{tabular}{|c|c|c|}
\hline Characteristics & Addis Ababa $(\mathrm{n}=20)$ & Jimma $(n=22)$ \\
\hline Average number of household members & $7( \pm 3)$ & $6( \pm 2)$ \\
\hline Average age of household head (HH) (years) & $43( \pm 15)$ & $47( \pm 10)$ \\
\hline Ratio of female to male headed household (F:M) & $1: 6$ & $1: 10$ \\
\hline Education level of $\mathrm{HH}$ (years) & $6( \pm 5)$ & $6( \pm 4)$ \\
\hline Farm size (ha) & $1.5( \pm 1)$ & $1.4( \pm 1)$ \\
\hline Partial $\mathrm{N}$ balance $\left(\mathrm{kg} \mathrm{N} \mathrm{ha}^{-1}\right.$ year $\left.^{-1}\right)$ & $138( \pm 219)$ & $89( \pm 198)$ \\
\hline Net farm income (NFI) (1000 ETB/ha/year) & $149( \pm 248)$ & $119( \pm 211)$ \\
\hline Average plot size (ha) & $0.3( \pm 0.16)$ & $0.2( \pm 0.12)$ \\
\hline Number of different crops per farm & $5( \pm 2)$ & $6( \pm 3)$ \\
\hline Average number of plots & $5( \pm 2)$ & $7( \pm 4)$ \\
\hline Livestock number in TLU & $9( \pm 9)$ & $6( \pm 4)$ \\
\hline Gross margin crops $\left.(1000 \mathrm{ETB} / \mathrm{ha} / \mathrm{year})^{\mathrm{a}}\right)$ & $57( \pm 72)$ & $36( \pm 67)$ \\
\hline Gross margin livestock (1000 ETB/ha/year) & $92( \pm 241)$ & $83( \pm 213)$ \\
\hline Distance from market (walking hours) & $0.7( \pm 0.5)$ & $1.2( \pm 0.8)$ \\
\hline Market share $(\%)$ & $66( \pm 24)$ & $8( \pm 121)$ \\
\hline Crop-livestock ratio (CLS) $(-)$ & $0.5( \pm 0.3)$ & $0.6( \pm 0.4)$ \\
\hline
\end{tabular}

Table 4 Mean N flows and income variables and standard deviation for MC-LS farms with crop (C) oriented and livestock (LS) oriented $\mathrm{N}$ allocation in Addis Ababa and Jimma

\begin{tabular}{|c|c|c|c|c|}
\hline \multirow[t]{3}{*}{$\mathrm{N}$ flows and income variables } & \multicolumn{4}{|l|}{$\mathrm{N}$ allocation } \\
\hline & \multicolumn{2}{|l|}{ Addis Ababa $(\mathrm{n}=20)$} & \multicolumn{2}{|l|}{$\operatorname{Jimma}(\mathrm{n}=22)$} \\
\hline & C oriented $(n=12)$ & LS oriented $(n=8)$ & C oriented $(n=12)$ & LS oriented $(n=10)$ \\
\hline Crop-livestock ratio (kg N/kg N) & $0.79 \pm 0.20$ & $0.19 \pm 0.23$ & $0.88 \pm 0.15$ & $0.17 \pm 0.16$ \\
\hline $\mathrm{N}$ inputs $\left(\mathrm{kg} \mathrm{N} \mathrm{ha}^{-1}\right.$ year $\left.^{-1}\right)$ & $106 \pm 38$ & $436 \pm 434$ & $43 \pm 57$ & $232 \pm 272$ \\
\hline $\mathrm{N}$ outputs $\left(\mathrm{kg} \mathrm{N} \mathrm{ha}^{-1}\right.$ year $\left.^{-1}\right)$ & $68 \pm 62$ & $148 \pm 158$ & $40 \pm 73$ & $41 \pm 37$ \\
\hline Partial $\mathrm{N}$ balance $\left(\mathrm{kg} \mathrm{ha}^{-1}\right.$ year $\left.^{-1}\right)$ & $38 \pm 67$ & $288 \pm 283$ & $3 \pm 99$ & $191 \pm 242$ \\
\hline $\mathrm{N}$ use efficiency farm level (\%) & $64 \pm 51$ & $34 \pm 58$ & $93 \pm 389$ & $18 \pm 91$ \\
\hline $\mathrm{N}$ use efficiency animal level (\%) & $29 \pm 19$ & $24 \pm 17$ & $19 \pm 17$ & $11 \pm 9$ \\
\hline $\mathrm{N}$ recycling index $(\%)$ & $11 \pm 19$ & $9 \pm 22$ & $43 \pm 32$ & $26 \pm 27$ \\
\hline Net farm income (1000 ETB/ha/year) & $105 \pm 125$ & $214 \pm 366$ & $52 \pm 91$ & $199 \pm 284$ \\
\hline
\end{tabular}

market orientation and income (Table 3). Jimma farms were smaller but had more plots compared to Addis Ababa farms. Female headed farms are more in Addis Ababa (1:6) than in Jimma (1:10). Farms in Addis Ababa were more market oriented (66\% market share) and had higher gross margin (GM) in both crop and livestock compartments than the farms in Jimma. Mean CLS ratios were rather similar in the two study sites, but the variation between farms was large. A total of 12 farms in both Addis Ababa and Jimma had allocated more $\mathrm{N}$ to the crop compartment and are hereafter categorized as MC-LS farms with crop oriented $\mathrm{N}$ allocation ( $\mathrm{CLS}>0.5)$. The remaining 8 farms in Addis Ababa and 10 farms in Jimma had allocated more $\mathrm{N}$ to the livestock compartment and are categorized as MC-LS farms with livestock oriented $\mathrm{N}$ allocation (CLS < 0.5) (Table 4 and Fig. 2).

$\mathrm{N}$ allocation impacts

Mean CLS significantly differed between MC-LS farms with crop oriented $\mathrm{N}$ allocation $(\mathrm{M}=0.79$, $\mathrm{SD}=0.20, \mathrm{n}=12$ ) and MC-LS farms with livestock oriented $\mathrm{N}$ allocation $(\mathrm{M}=0.19, \mathrm{SD}=0.23, \mathrm{n}=8)$ at 


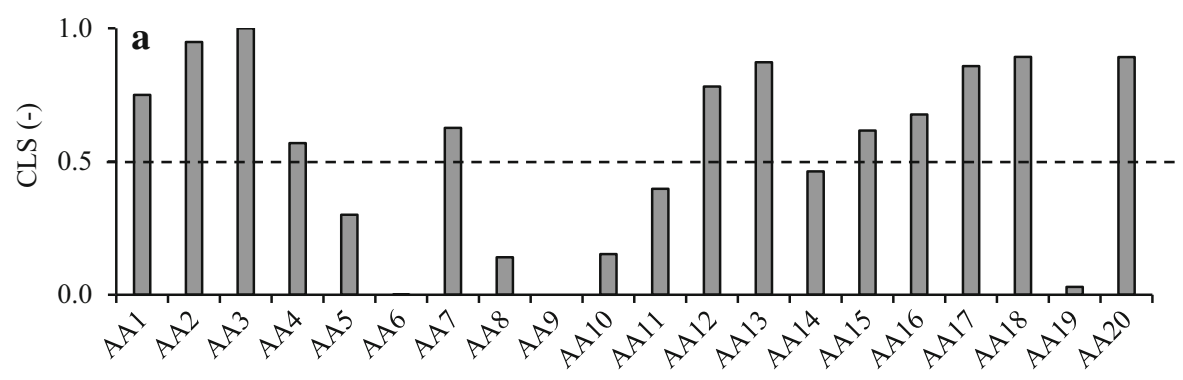

Mixed crop-livestock (MC-LS) farms at Addis Ababa (AA1-20)

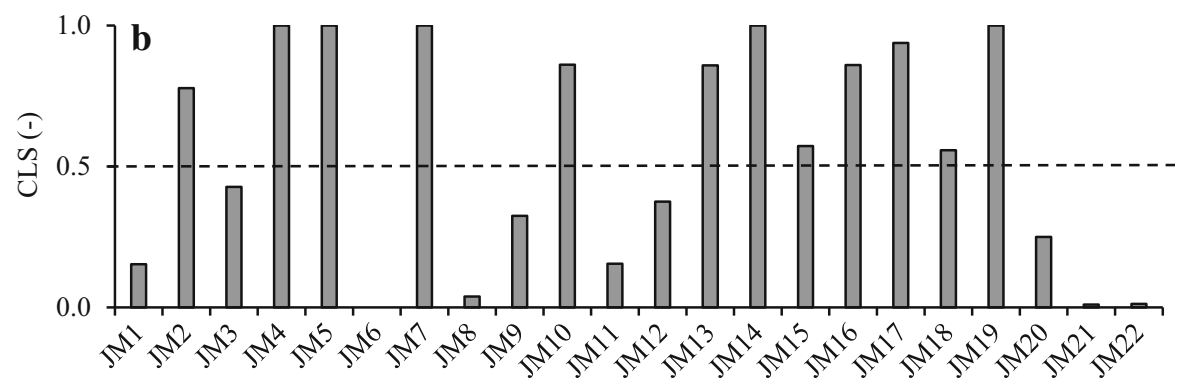

Mixed crop-livestock (MC=LS) farms at Jimma (JM1-22)

Fig. 2 Crop-livestock ratio (CLS) of mixed crop-livestock (MC-LS) farms: a indicating 12 farms with crop oriented $\mathrm{N}$ allocation (CLS $>0.5$ ) above the broken line at CLS of 0.5 and 8 farms with livestock oriented $\mathrm{N}$ allocation $(\mathrm{CLS}<0.5)$ below

0.05 level of significance $(\mathrm{t}=6.13, \mathrm{df}=18, p<0.05)$ in Addis Ababa. Similarly, mean CLS significantly differed between MC-LS farms with crop oriented $\mathrm{N}$ allocation $(\mathrm{M}=0.88, \mathrm{SD}=0.15, \mathrm{n}=12)$ and farms with livestock oriented $\mathrm{N}$ allocation $(\mathrm{M}=0.17, \mathrm{SD}=$ $0.16, \mathrm{n}=10)$ at 0.05 level of significance $(\mathrm{t}=10.67$, df $=18, p<0.05$ ) in Jimma (Table 4). Marketed $\mathrm{N}$ inputs were much higher in Addis Ababa than in Jimma, and $\mathrm{N}$ inputs were much higher in farms with livestock oriented $\mathrm{N}$ allocation than in farms with crop oriented $\mathrm{N}$ allocation (Table 4). MC-LS farms with livestock oriented $\mathrm{N}$ allocation had four to five times more $\mathrm{N}$ input than MC-LS farms with crop oriented $\mathrm{N}$ the broken line at CLS of 0.5 at Addis Ababa and b similarly showing 12 crop oriented and 10 livestock oriented MC-LS farms at Jimma

allocation. In Addis Ababa, PNB was 38 and $288 \mathrm{~kg} \mathrm{~N}$ $\mathrm{ha}^{-1}$ year $^{-1}$ for farms with crop oriented $\mathrm{N}$ allocation and livestock oriented $\mathrm{N}$ allocation, respectively. In Jimma, PNB was 3 and $191 \mathrm{~kg} \mathrm{~N} \mathrm{ha}^{-1}$ year $^{-1}$ for MC-LS farms with crop oriented $\mathrm{N}$ allocation and livestock oriented $\mathrm{N}$ allocation (Table 4).

Mean NUE both at system level and animal level was higher in farms with crop oriented $\mathrm{N}$ allocation than in farms with livestock oriented $\mathrm{N}$ allocation in both study areas (Table 4). Mean NRI was relatively low in Addis Ababa; $11 \%$ in farms with crop oriented $\mathrm{N}$ allocation and $9 \%$ in farms with livestock oriented $\mathrm{N}$ allocation. In Jimma, NRI was $43 \%$ in farms with crop oriented $\mathrm{N}$

Table 5 Summary of Linear Regression Analyses for relations between N allocation (CLS) and N flows and net farm income (NFI) of peri-urban MC-LS farms in Addis Ababa $(\mathrm{N}=20)$ and Jimma $(\mathrm{N}=22)$

\begin{tabular}{|c|c|c|c|c|c|c|c|c|c|}
\hline \multirow[t]{2}{*}{ Variable } & & \multicolumn{4}{|c|}{ Addis Ababa } & \multicolumn{4}{|l|}{ Jimma } \\
\hline & & IN & $\mathrm{ON}$ & PNB & NFI & IN & $\mathrm{ON}$ & PNB & NFI \\
\hline \multirow[t]{3}{*}{ CLS } & $\beta$ & $-0.66^{* *}$ & $-0.55^{*}$ & $-0.65 * *$ & $-0.72 * *$ & $-0.63^{* *}$ & $-0.01^{\mathrm{ns}}$ & $-0.65 * *$ & $-0.46^{*}$ \\
\hline & $R^{2}$ & 0.43 & 0.30 & 0.43 & 0.52 & 0.40 & 0 & 0.42 & 0.21 \\
\hline & $F$ & $13.73 * *$ & $7.6^{*}$ & $13.06 * *$ & $19.87 * *$ & $12.83 * *$ & $0.003^{\mathrm{ns}}$ & $14.39 * *$ & $5.38 *$ \\
\hline
\end{tabular}

$\beta$ Beta, $n s$ non significant difference $(p>0.05)$, *significant difference at $p<0.05$ and **significant difference at $p<0.01, I N \mathrm{~N}$ input, $O N \mathrm{~N}$ output, $P N B$ Partial N balance 


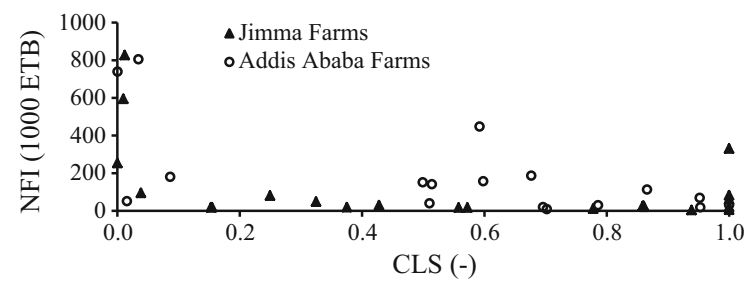

Fig. 3 Net farm income (NFI) variations and relations with CLS (N allocation) in MC-LS farms of Addis Ababa and Jimma

allocation and $26 \%$ in farms with livestock oriented $\mathrm{N}$ allocation (Table 4). CLS ratio was significantly related to $\mathrm{N}$ flows in MC-LS farms and explained 40-43\% variance in $\mathrm{N}$ input, $0-30 \%$ variance in $\mathrm{N}$ output and $42-43 \%$ variance in PNB (Table 5).

The NFI of MC-LS farms' was also significantly related to CLS ratio in both study areas (Table 5). Farms with livestock oriented $\mathrm{N}$ allocation had on average two to four times higher NFI than farms with crop oriented $\mathrm{N}$ allocation (Table 4). However, the variation in NFI among farms within both cities was enormous (Fig. 3).
Correlation analysis among $\mathrm{N}$ flows and farm income indicators

In Addis Ababa, $\mathrm{N}$ output, partial $\mathrm{N}$ balance (PNB), gross margin of livestock (GML) and net farm income (NFI) were positively correlated to total $\mathrm{N}$ input (Table 6). PNB was positively correlated to GML and NFI. In Jimma, NFI was positively related to GML, N input, and PNB. $\mathrm{N}$ recycling index (NRI) was negatively correlated to $\mathrm{N}$ input, $\mathrm{N}$ output, $\mathrm{PNB}$, GML and NFI (Table 7).

Sensitivity analysis of NUE and N recycling at farm system level

At a low NUE (5\%) at animal level, system level NUE of MC-LS farms will likely range between 13 and $17 \%$, while at high NUE (35\%) at animal level, it may range between 37 and $51 \%$, depending also on the CLS ratio (Fig. 4). Farm system NUE is much higher in MC-LS farms with crop oriented $\mathrm{N}$ allocation; for example at CLS ratio $=0.8$, system level NUE will

Table 6 Pearson correlations among N flows and income indicators for MC-LS farms in Addis Ababa peri-urban areas

\begin{tabular}{|c|c|c|c|c|c|c|c|}
\hline & IN & $\mathrm{ON}$ & PNB & NRI & GMC & GML & NFI \\
\hline $\mathrm{N}$ input (IN) (kg/ha/year) & 1.00 & $.88^{* *}$ & $.97 * *$ & -.28 & -.13 & $.97 * *$ & $.94 * *$ \\
\hline $\mathrm{N}$ output $(\mathrm{ON})(\mathrm{kg} / \mathrm{ha} / \mathrm{year})$ & & 1.00 & $.73 * *$ & -.35 & .19 & $.84 * *$ & $.89 * *$ \\
\hline Partial N balance (PNB) (kg N/ha/year) & & & 1.00 & -.21 & -.39 & $.87 * *$ & $.77 * *$ \\
\hline $\mathrm{N}$ recycling index (NRI) $(\%)$ & & & & 1.00 & -.20 & -.18 & -.23 \\
\hline Gross margin of crops (GMC) (ETB) & & & & & 1.00 & -.05 & .24 \\
\hline Gross margin of livestock (GML) (ETB) & & & & & & 1.00 & $.96^{* *}$ \\
\hline Net farm income (NFI) (ETB) & & & & & & & 1.00 \\
\hline
\end{tabular}

*Correlation is significant at the 0.05 level of significance

**Correlation is significant at the 0.01 level of significance

Table 7 Pearson correlations among N flows and income indicators for MC-LS farms in Jimma peri-urban areas

\begin{tabular}{|c|c|c|c|c|c|c|c|}
\hline & IN & $\mathrm{ON}$ & PNB & NRI & GMC & GML & NFI \\
\hline $\mathrm{N}$ input (IN) (kg/ha/year) & 1.00 & .28 & $.96^{* *}$ & $-.56 * *$ & -.21 & $.86^{* *}$ & $.80 * *$ \\
\hline $\mathrm{N}$ output $(\mathrm{ON})(\mathrm{kg} / \mathrm{ha} / \mathrm{year})$ & & 1.00 & -.00 & $-.50 *$ & $.80 * *$ & .35 & $.61 * *$ \\
\hline Partial N balance (PNB) (kg N/ha/year) & & & 1.00 & $-.43 *$ & $-.46^{*}$ & $.79 * *$ & $.66 * *$ \\
\hline $\mathrm{N}$ recycling index $(\mathrm{NRI})(\%)$ & & & & 1.00 & -.24 & $-.46^{*}$ & $-.54 * *$ \\
\hline Gross margin of crops (GMC) (ETB) & & & & & 1.00 & -.19 & .13 \\
\hline Gross margin of livestock (GML) (ETB) & & & & & & 1.00 & $.95 * *$ \\
\hline Net farm income (NFI) (ETB) & & & & & & & 1.00 \\
\hline
\end{tabular}

*Correlation is significant at the 0.05 level of significance

**Correlation is significant at the 0.01 level of significance 


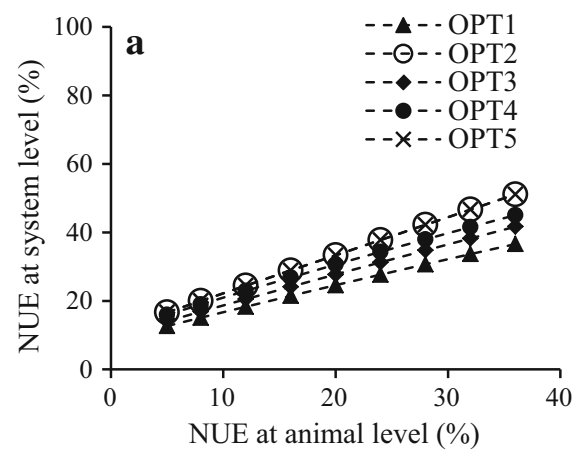

Fig. 4 Relations between NUE at animal level and NUE at system level, calculated using various $\mathrm{N}$ management options related to internal $\mathrm{N}$ recycling and $\mathrm{N}$ recovery applied in crop and livestock production a for MC-LS farms with livestock

range between 31 and $56 \%$ at a low NUE (5\%) at animal level, while it may range between 38 and $65 \%$ at a high NUE (35\%) at animal level (Fig. 4b). The estimated mean NUE at animal level was $29 \%$ for crop oriented and $24 \%$ for livestock oriented MC-LS farms in Addis Ababa and 19\% for crop oriented and 11\% for livestock oriented MC-LS farms in Jimma (Table 4). The relatively high NUE at animal level in Addis Ababa reflects probably that farmers may tend to overestimate the milk yield per cow per year compared to literature data. This could be attributed to the absence of proper monitoring and farm record keeping as observed in field data collection. Further, the estimated NUE at system level for livestock oriented farms were 34 and 18\%, respectively (Table 4). These values match with a relatively low recovery of manure $\mathrm{N}$ and a low utilization of manure and fertilizer $\mathrm{N}$, i.e., similar to option 1 in Table 2.

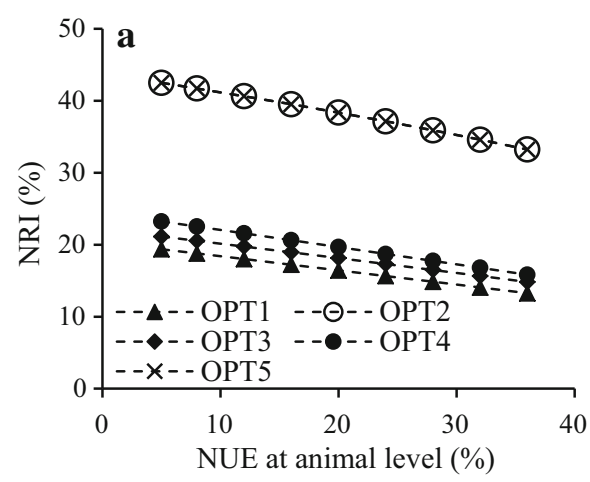

Fig. 5 Relations between N recycling index (NRI) and NUE at animal level, calculated using $\mathrm{N}$ management options related to $\mathrm{N}$ recovery applied in crop and livestock production a for MC-

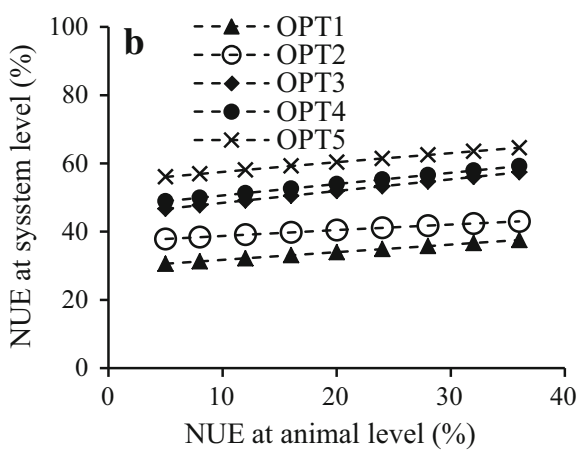

oriented $\mathrm{N}$ allocation at CLS: 0.2 and $\mathbf{b}$ for farms with crop oriented $\mathrm{N}$ allocation at CLS: 0.8 . Options (OPT) are explained in Table 2

Improvements in system level NUE will differ with $\mathrm{N}$ allocation (CLS) (Fig. 4). MC-LS farms with livestock oriented $\mathrm{N}$ allocation $(\mathrm{CLS}=0.2)$ and a modest NUE (20\%) at animal level may improve the current system level NUE up to about $35 \%$ and to about 50\% when NUE at animal level is $35 \%$ (Fig. 4a). MC-LS farms with crop oriented $\mathrm{N}$ allocation (CLS $=0.8$ ), may improve the system level NUE up to $50-65 \%$ (Fig. 4b). In MC-LS farms with livestock oriented $\mathrm{N}$ allocation, OPT2 and OPT5 will equally give a high system level NUE as fertilizer N use is negligible (Fig. 4a). The improvement in system level NUE of MC-LS farms is reflected in N recycling index (NRI). Evidently, increasing NUE at animal level from 5 to $35 \%$ will decrease NRI because manure $\mathrm{N}$ production decreases with an increase in NUE at animal level, depending also on the CLS ratio (Fig. 5). For livestock oriented $\mathrm{N}$ allocation, there is a

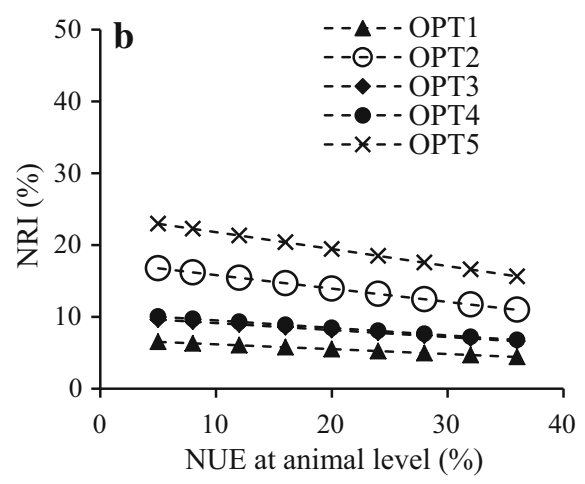

LS farms with livestock oriented $\mathrm{N}$ allocation at CLS: 0.2 and b for MC-LS farms with crop oriented N allocation at CLS: 0.8. Options (OPT) are explained in Table 2 
relatively large difference in NRI between options 1,3 and 4 and options 2 and 5 (Fig. 5a). This is mainly related to the differences in manure $\mathrm{N}$ recovery, and subsequent manure $\mathrm{N}$ utilization. In options 2 and 5, it is assumed that all urine and faeces are collected, and that only $30 \%$ of the excreted $\mathrm{N}$ will be lost before application of the manure to crop land. In contrast, urine collection is negligible and hence $\mathrm{N}$ losses are high (70\%) in options 1, 3, and 4. The differences in urine (and faeces) collection have a large effect on NRI when CLS ratio is low (Fig. 5a).

The mean NRI was much higher in Jimma than in Addis Ababa (Table 4). The mean NRI of Jimma is somewhat at the upper range of values presented in Fig. 5, while the mean NRI values of Addis Ababa is at the lower range of values in Fig. 5. The relatively high NRI values in Jimma are also the result of the low $\mathrm{N}$ input; conversely, the relatively low NRI in Addis Ababa reflects a relatively high $\mathrm{N}$ input (Table 4).

\section{Discussion}

\section{Effects of $\mathrm{N}$ allocation}

The crop-livestock ratio (CLS) differed greatly between MC-LS farms in both study areas (Table 4), and enabled us to differentiate MC-LS peri-urban farms into MC-LS farms with crop oriented $\mathrm{N}$ allocation and MC-LS farms with livestock oriented $\mathrm{N}$ allocation. MC-LS farms with livestock oriented $\mathrm{N}$ allocation had higher $\mathrm{N}$ inputs, PNB, and NFI than crop oriented MC-LS farms. Livestock oriented farms mostly used confinement-based feeding and purchased a significant fraction of the feed. Clearly, the CLS indicator has a large diagnostic value for characterizing MC-LS farms.

The differences observed in $\mathrm{N}$ allocation in MC-LS farms are related in part to resource constraints such as shortage of land, crop residue and capital (Tadesse et al. 2018), which creates internal competition within a farm. With an increase in animal output, crop residues are becoming limited resources in MC-LS farms, which creates pressure and trade-offs (Valbuena et al. 2015). The system configuration with the highest purchasing power ensues from this competition, and decisions about investments in $\mathrm{N}$ inputs for either crop or livestock compartments within a farm is dictated accordingly. Homann-Kee Tui et al. (2015), reported that nutrient resources in crop production and livestock husbandry are often limited, and create short and long-term trade-offs in nutrient allocation.

Mean CLS was negatively related to NFI, because livestock oriented MC-LS farms $(\mathrm{CLS}<0.5)$ allocated more external $\mathrm{N}$ input to their livestock compartment and had increased their productivity and hence increased their NFI. Conversely, livestock oriented MC-LS farms had higher NFI and imported more external $\mathrm{N}$ input that resulted in lower CLS (Tables 4, 5). Accordingly, MC-LS farms with a low CLS (0.2) had two to four times more NFI than farms with high CLS (0.8) (Table 4). Hence, the economic performance of the livestock oriented MC-LS farms was rather similar to the specialized livestock farms in the urban and peri-urban environments of Addis Ababa and Jimma (Tadesse et al. 2018). Conversely, the performance of the crop oriented MC-LS farms was rather similar to the specialized crop farms. Crop oriented MC-LS farms still keep livestock, because animals perform important non-market roles. Tarawali et al. (2011), indicated that up to $40 \%$ of the benefits from livestock, especially cattle keeping came from non-market, intangible benefits, mostly insurance, financing and draught power.

MC-LS farms with crop oriented $\mathrm{N}$ allocation had relatively low PNB, for two reasons. First, the available crop residues were mainly used as biofuel and feed, animal manures were used as biofuel and not for soil fertility amendment. As a result, crop yields were relatively low. Second, because of the low crop yields farmers had low income and were unable to purchase fertilizers. According to Homann-Kee Tui et al. (2015), feeding crop residues to livestock is often accompanied with using manure as fuel, at the expense of soil fertility amendment. Hence, the need for energy by households is at the cost of soil fertility management (Alvarez et al. 2014), also because ashes are not well utilized. Negash et al. (2017) reported that application of crop residues and manure for soil fertility management is limited because of competitive use for household energy.

MC-LS farms with crop oriented $\mathrm{N}$ allocation had higher $\mathrm{N}$ use efficiency than MC-LS farms with livestock oriented $\mathrm{N}$ allocation (Table 4 ). This finding is in agreement with the general observation that manure $\mathrm{N}$ is vulnerable to various loss processes and hence that system level NUE is usually much less in livestock production than in crop production systems 
(Goulding et al. 2008). The internal nutrient recycling is considered one of the most beneficial features of MC-LS farming systems (Rufino et al. 2006, 2009). However, N recycling was relatively low (9-43\%) in the MC-LS farms across the study areas (Table 4) and did not differ much between crop oriented and livestock oriented MC-LS farms. This low N recycling could be due to the challenge that animal manure and crop residues are contested for fuel in peri-urban areas of Addis Ababa and Jimma. Negash et al. (2017), reported that the use of manure for fuel instead of soil fertility amendment has reduced agricultural gross domestic production (GDP) of Ethiopia by $\sim 7 \%$, via soil degradation and low crop yields. Correlation analyses revealed negative correlations between NRI and $\mathrm{N}$ input, $\mathrm{N}$ output, PNB and NFI (Table 7). This suggests that farms with relatively high external $\mathrm{N}$ imports had low $\mathrm{N}$ recycling; crop residues and manures were used for fuel or were wasted, and not used for soil fertility management. About $85 \%$ of the crop residues are used for either livestock feed or energy in Ethiopia (Agegnehu and Amede 2017), while manures including urine and ashes are not effectively collected, stored and reutilized (Negash et al. 2017).

Available labour and lack of regulations are also major barriers for the effective collection and recycling of animal manures. Use of inorganic $\mathrm{N}$ fertilizers requires much less labour than careful manure management. Yu et al. (2017) reported that farmers became more willing to use inorganic fertilizers than the labour-intensive crop residues and manures, the latter often requires composting before application. Clearly, the cost of labour for manure management is one of the barriers for $\mathrm{N}$ recycling. On the other hand, there is lack of formal requirements to collect and store manures properly prior to application to land. Many livestock farms have no leak-tight stables and manure storage systems, and much of the liquid fraction thus simply disappears and not actively applied to crop lands.

Interestingly, $\mathrm{N}$ output and NFI are negatively related to NRI (Table 7). This suggests that the effects of external $\mathrm{N}$ inputs are much greater than the effects of recycled N. Further, it indicates that the costs of external inputs are relatively low relative to the gain in output. The purchase of concentrate feed and fertilizers adds also to the status of the farmers; the use of inorganic fertilizers instead of organic amendments is considered an indication for the wealth of the household, and the best way to increase agricultural productivity. Besides, government policies are encouraging the use of inorganic fertilizers as reported in Howard et al. (2003).

Sensitivity analyses of NUE at farm system level

System level NUE greatly depends on NUE at animal level, manure $\mathrm{N}$ loss, and manure and fertilizer $\mathrm{N}$ recovery in harvested plant biomass (Liu et al. 2017). Our analyses indicate that the farm system level NUE also depends on the CLS ratio (Fig. 4). System level NUE of livestock oriented MC-LS farms are likely in the range of 10-40\%, depending on the NUE at animal level and the utilization of manure and fertilizers (if any). System level NUE of crop oriented MC-LS farms are likely in the range of 30-60\% (Fig. 4). De Klein et al. (2017) reported a whole-farm NUE of grassland-based dairy farms in the range of $10-65 \%$, and Liu et al. (2017) arrived at a maximum possible system level NEU of MC-LS farms of 70\%. Alvarez et al. (2014), reported system level NUE of 2-50\% depending on manure management and concentrate supply in MC-LS systems in Madagascar.

Improvements in system level NUE depend in part on $\mathrm{N}$ allocation within MC-LS farms (Fig. 4). In MCLS farms with livestock oriented $\mathrm{N}$ allocation (CLS: 0.2) improvements in system level NUE are firstly related to improvements in NUE at animal level and secondly through the improved recovery and utilization of manure N. MC-LS farms with crop oriented N allocation (CLS: 0.8) gain more from the improvements in the recovery of fertilizer and manure $\mathrm{N}$ than from improvements in NUE at animal level (Fig. 4b). Powell and Rotz (2015) indicated that reductions in dietary crude protein to reduce $\mathrm{N}$ losses from dairy farms, may decrease the fertilizer $\mathrm{N}$ value of manure and manure $\mathrm{N}$ use efficiency. Similar to the improvement in NUE at animal level, a shift in dairy cow diets from alfalfa silage to low-protein corn silage significantly reduced concentrations of inorganic $\mathrm{N}$ in the manure, which have profound impacts on the $\mathrm{N}$ recycling and manure $\mathrm{N}$ availability to crops (Powell and Rotz 2015). The relatively high mean NUE at animal level in Addis Ababa; 29\% in crop oriented and $24 \%$ in livestock oriented MC-LS farms (Table 4) is likely the result of high-yielding dairy cows and modest levels of crude protein in the ration (13-15\%), 
but overestimating milk yields by farmers cannot be excluded. The relatively low mean NUE at animal level in Jimma; $19 \%$ in crop oriented and $11 \%$ in livestock oriented MC-LS farms (Table 4) is likely the result of a genetically low yielding cows and low quality feed. In agreement, Rufino et al. (2006) reported that for high yielding dairy cows, increasing the dietary $\mathrm{N}$ increases the milk yield only when $\mathrm{N}$ is more limiting than the energy requirements of the cow and provided that the amino acid composition of the diet meets the requirements for milk production. But for poor quality feed that doesn't provide the amino acid composition required for milk production, greater dietary $\mathrm{N}$ intake simply results in a greater excretion of $\mathrm{N}$ and reduces NUE. The large difference in mean NUE at animal level in Addis Ababa and Jimma indicate that different strategies: the genetic improvement of livestock breeds; feed quality improvement and precision feeding; NUE and $\mathrm{N}$ recycling enhancing measures (exchange of crop residues and manure between crop and livestock activities within and between farms), and provision of alternative and low cost energy sources for satisfaying the fuel demand of the farming families will be needed to improve the performance of livestock oriented MC-LS farms. Similarly, Shikuku et al. (2017) suggested promotion of improved feeding strategies and introduction of more efficient breeds of livestock to achieve increased productivity of MC-LS systems. Therefore, both feed quality and the genetic basis of the herd will have to be improved first in livestock oriented MC-LS farms in Jimma.

\section{Conclusions}

We introduced a quantitative indicator (CLS ratio) as a first attempt to characterize the relative allocation of external $\mathrm{N}$ inputs to the soil/crop and livestock compartments in MC-LS farms, and to relate CLS ratio to NUE, PNB and farm income. Accordingly, our results have the following important insights and policy implications.

- CLS ratio is proved to be a key indicator for the characterization of MC-LS farms; as farm income (NFI), PNB and NUE at farm level are all related to CLS ratio.
- Lower CLS ratio was associated with large external $\mathrm{N}$ input allocation to the livestock than the crop compartment and thus MC-LS farms with livestock oriented $\mathrm{N}$ allocation had four to five times higher $\mathrm{N}$ input, more than seven times higher PNB and two to four times higher NFI than farms with crop oriented $\mathrm{N}$ allocation.

- $\mathrm{N}$ allocation significantly varied between MC-LS farms in both study areas, indicating that MC-LS farms are diverse and that competetion occurs between crop and livestock compartments within a farm.

- Sensitivity analyses suggests that through promotion of improved manure management and introduction of more efficient livestock breeds, the NUE of MC-LS farms can be improved by $20-25 \%$ and $\mathrm{N}$ recycling by $10-20 \%$ over the current condition.

Therefore, to improve the environmental and economic performance of MC-LS peri-urban farms in Ethiopia (1) NUE and N recycling enhancing measures including livestock feed quality improvement, exchange of crop residues and manure between crop and livestock compartments within and between farms, and provision of alternative and low cost energy sources for satisfying the fuel demand of the farming families; in combination with (2) improving the NUE at animal level through animal breeding for the genetic improvement of livestock breeds and precision animal feeding; should be put in practice. Due to the extreme shortage of land in urban and periurban areas, future research should incorporate the effects of changing land allocation as a key aspect in the sensitivity analysis of the impacts of improved livestock breeding and feeding strategies of MC-LS farms.

Acknowledgements This study was part of the CASCAPE Project (Capacity building for scaling up of evidence-based best practices in agricultural production in Ethiopia). The Project is funded by the Dutch Ministry of Foreign Affairs through the Embassy of the Kingdom of The Netherlands in Addis Ababa, Ethiopia (Grant No.: 5120915001). We are also grateful to the staff of Addis Ababa and Jimma urban Agriculture offices for their vital role in field data collection.

Open Access This article is distributed under the terms of the Creative Commons Attribution 4.0 International License (http:// creativecommons.org/licenses/by/4.0/), which permits unrestricted use, distribution, and reproduction in any medium, provided you give appropriate credit to the original 
author(s) and the source, provide a link to the Creative Commons license, and indicate if changes were made.

\section{References}

Agegnehu G, Amede T (2017) Integrated soil fertility and plant nutrient management in tropical agro-ecosystems: a review. Pedosphere 27:662-680

Alvarez S, Rufino MC, Vayssières J, Salgado P, Tittonell P, Tillard E, Bocquier F (2014) Whole-farm nitrogen cycling and intensification of crop-livestock systems in the highlands of Madagascar: an application of network analysis. Agric Syst 26:25-37

Banerjee A, Chakrabarty M, Rakshit N, Mukherjee J, Ray S (2017) Indicators and assessment of ecosystem health of Bakreswar reservoir, India: an approach through network analysis. Ecol Ind 80:163-173

Blummel M, Homann-Kee Tui S, Valbuena D, Duncan AJ, Herrero M (2013) Biomass in crop-livestock systems in the context of the livestock revolution. Secheresse 24:330-339. https://doi.org/10.1684/sec.2013.0403

Cassidy ES, West PC, Gerber JS, Foley JA (2013) Redefining agricultural yields: from tonnes to people nourished per hectare. Environ Res Lett. https://doi.org/10.1088/17489326/8/3/034015

De Klein CAM, Monaghan RM, Alfaro M, Gourley CJP, Oenema O, Powell JM (2017) Nitrogen performance indicators for dairy production systems. Soil Res 55:479-488

Duncan AJ, Tarawali SA, Thorne PJ, Valbuena D, Descheemaeker K, Homann-Kee Tui S (2013) Integrated croplivestock systems-a key to sustainable intensification in Africa. Trop Grassl Forrajes Trop 1:202-206

Goulding K, Jarvis S, Whitmore A (2008) Optimizing nutrient management for farm systems. Philos Trans R Soc Lond B Biol Sci 363:667-680

Gupta V, Rai PK, Risam KS (2012) Integrated crop-livestock farming systems: a strategy for resource conservation and environmental sustainability. Indian Res J Ext Educ 2:49-54

Haile Mariam A, Adugna A (2011) Migration and urbanization in Ethiopia: addressing the spatial imbalance. In: Teller C, Haile Mariam A (eds) The demographic transition and development in Africa: the unique case of Ethiopia. Springer, New York, pp 145-165. https://doi.org/10.1007/ 978-90-481-8918-2-8

Homann-kee Tui S, Valbuena D, Masikati P, Descheemaeker K, Nyamangara J, Claessens L, Erenstein O, Van Rooyen A, Nkomboni D (2015) Economic trade-offs of biomass use in crop-livestock systems: exploring more sustainable options in semi-arid Zimbabwe. Agric Syst 134:48-60

Howard J, Crawford E, Kelly V, Demeke M, Jeje JJ (2003) Promoting high-input maize technologies in Africa: the Sasakawa-Global 2000 experience in Ethiopia and Mozambique. Food Policy 28:335-348

Kindu M, Duncan AJ, Valbuena D, Gérard B, Dagnachew L, Mesfin B, Gedion J (2014) Intensification of crop-livestock farming systems in East Africa: a comparison of selected sites in the highlands of Ethiopia and Kenya. In: Vanlauwe
B, van Asten P, Blomme G (eds) Challenges and opportunities for agricultural intensification of the humid highland systems of SSA. Springer, Cham, pp 19-28. https:// doi.org/10.1007/978-3-319-07662-1-2

Liu Q, Wang J, Bai Z, Ma L, Oenema O (2017) Global animal production and nitrogen and phosphorus flows. Soil Res 55:451-462

Marton S, Zimmermann A, Kreuzer M, Gaillard G (2016) Comparing the environmental performance of mixed and specialised dairy farms: the role of the system level analysed. J Clean Prod 124:73-83

Negash D, Abegaz A, Smith JU, Araya H, Gelana B (2017) Household energy and recycling of nutrients and carbon to the soil in integrated crop-livestock farming systems: a case study in Kumbursa village, Central Highlands of Ethiopia. GCB Bioenergy 9:1588-1601

Powell JM, Rotz CA (2015) Measures of nitrogen use efficiency and nitrogen loss from dairy production systems. J Environ Qual 44:336-344

Rufino MC, Rowe EC, Delve RJ, Giller KE (2006) Nitrogen cycling efficiencies through resource-poor African croplivestock systems. Agric Ecosyst Environ 112:261-282

Rufino MC, Hengsdijk H, Verhagen A (2009) Analysing integration and diversity in agro-ecosystems by using indicators of network analysis. Nutr Cycl Agroecosyst $84: 229-247$

Ryschawy J, Choisis N, Choisis JP, Joannon A, Gibon A (2012) Mixed crop-livestock systems: an economic and environmental-friendly way of farming? Animal 6:1722-1730

Satterthwaite D, Mcgranahan G, Tacoli C (2010) Urbanization and its implications for food and farming. Philos Trans R Soc Lond B Biol Sci 365:2809-2820

Shikuku KM, Valdivia RO, Paul BK, Mwongera C, Winowiecki L, Läderach P, Herrero M, Silvestri S (2017) Prioritizing climate-smart livestock technologies in rural Tanzania: a minimum data approach. Agric Syst 151:204-216

Sneessens I, Veysset P, Benoit M, Lamadon A, Brunschwig G (2016) Direct and indirect impacts of crop-livestock organization on mixed crop-livestock systems sustainability: a model-based study. Animal 10:1911-1922

Strokal M, Ma L, Bai Z, Luan S, Kroeze C, Oenema O, Velthof G, Zhang F (2016) Alarming nutrient pollution of Chinese rivers as a result of agricultural transitions. Environ Res Lett. https://doi.org/10.1088/1748-9326/11/2/024014

Tadesse ST, Oenema O, Van Beek C, Ocho FL (2018) Diversity and nutrient balances of urban and peri-urban farms in Ethiopia. Nutr Cycl Agroecosyst 111:1-18

Tarawali S, Herrero M, Descheemaeker K, Grings E, Blümmel M (2011) Pathways for sustainable development of mixed crop livestock systems: taking a livestock and pro-poor approach. Livest Sci 139:11-21

Thornton PK (2010) A review: livestock production: recent trends, future prospects. Philos Trans $\mathrm{R}$ Soc 365:2853-2867

Tittonell P, van Wijk MT, Rufino MC, Vrugt JA, Giller KE (2007) Analysing trade-offs in resource and labour allocation by smallholder farmers using inverse modelling techniques: a case-study from Kakamega district, western Kenya. Agric Syst 95:76-95

Valbuena D, Tui SH, Erenstein O, Teufel N, Duncan A, Abdoulaye T, Swain B, Mekonen K, Germaine I, Gerard B 
(2015) Identifying determinants, pressures and tradeoffs of crop residue use in mixed smallholder farms in Sub-Saharan Africa and South Asia. Agric Syst 134:107-118

Van Beek CL, Onduru DD, Gachimbi LN, de Jager A (2009) Farm nutrient flows of four farmer field schools in Kenya. Nutr Cycl Agroecosyst 83:63-72

Van Beek CL, Meerburg BG, Schils RLM, Verhagen J, Kuikman PJ (2010) Feeding the world's increasing population while limiting climate change impacts: linking $\mathrm{N}_{2} \mathrm{O}$ and $\mathrm{CH}_{4}$ emissions from agriculture to population growth. Environ Sci Policy 13:89-96

Vlaming J, van Beek CL, Heinen M, van Duivenbooden N (2012) MonQI monitoring for quality improvement MonQI basic user manual. www.monqi.org
Wang HJ, Huang B, Shi XZ, Darilek JL, Yu DS, Sun WX, Zhao YC, Chang Q, Öborn I (2008) Major nutrient balances in small-scale vegetable farming systems in peri-urban areas in China. Nutr Cycl Agroecosyst 81:203-218

Wang F, Wang Z, Kou C, Ma Z, Zhao D (2016) Responses of wheat yield, macro- and micro-nutrients, and heavy metals in soil and wheat following the application of manure compost on the North China Plain. PLoS ONE 11:1-18

Yu C, Xiao Y, Ni S (2017) Changing patterns of urban-rural nutrient flows in China: driving forces and options. Sci Bull 62:83-91

Zasada I (2011) Multifunctional peri-urban agriculture-A review of societal demands and the provision of goods and services by farming. Land Use Policy 28:639-648 